\title{
EENIGE AANVULLINGEN OP DE ENCYCLOPAEDIE VAN NEDERLANDSCH WEST-INDIE
}

\author{
DE BELASTINGEN IN SURINAME
}

\section{I}

DOOR

C. R. WEYTINGH

Groep A. Invoerrechten en Accijnsen.

\section{Invoerrechten.}

De Verordening van 10 Mei 1887 (G.B. No. 25) omtrent de heffing van in- en uitvoerrechten met al de daarin aangebrachte wijzigingen en aanvullingen is krachtens art. 32 al. 3 van de Verordening van 10 Mei 1922 (G.B. No. 54) omtrent de heffing van invoerrechten vervallen; bij deze Verordening, welke op 1 Januari 1923 in werking trad en wordt aangehaald als de „Tarief verordening 1922", werd een nieuw tarief van invoerrechten vastgesteld.

Bij dit tarief, dat zuiver fiscaal is, zijn met namen vermeld 54 posten, waarvoor een speciaal recht is vastgesteld.

Naar de waarde zijn belast:

4 posten t.w.: $a$. (cement, kalk en tras); $b$. (pik en teer); $c$. (verfwaren); en $d$. (vernissen, lakken, politoeren en siccatieven) met $7 \% ; 1$ post tw. shoulders (gepekeld vleesch) met $10 \% ; 10$ posten t.w.: $a$. (blom en meel van granen in verpakking van één kilogram of minder); $b$. (chloralhydraat en andere uit of met alcohol of houtgeest bereide chemische producten, geen dranken zijnde); c. (geneesmiddelen, niet verpakt voor dadelijk gebruik en niet bestemd voor den verkoop in het klein); $d$. (zeemleer en perkament e. (eetbare oliën, in verpakking van 10 Liters inhoud of minder); $f$. (schrijf-, bureau- en teekenbehoeften); $g$. (vetten in verpakking van 10 kilogram netto en minder); $h$. visch, met uitzondering van gezouten of gepekelde visch); $i$. (vleesch en spek, niet gepekeld); 
$j$. (medicinale zeepsoorten, alsmede tandzeep, tandpoeder en tandpasta) met $15 \% ; 2$ posten t.w. $a$. (geweer- en pistoolkogels, hagels en patronen); $b$. muziekinstrumenten, behalve automatisch werkende z.a. gramafonen en pianola's) met $20 \%$; 2. posten t.w. $a$. fotografietoestellen en benoodigdheden hiervoor); $b$. (vloeibare koolzuur) met $25 \%$; 1 post t.w. geparfumeerde zeep, geparfumeerde zeeppoeder en andere fijne zeepsoorten, met $27 \frac{1}{2} \%$; 5 posten t.w. $a$. (goud-, zilver- en platinawerk, geheel of gedeeltelijk voltooid); $b$. (juweelen, paarlen en edelgesteenten); $c$. (gramafonen en dergelijke automatisch werkende muziekinstrumenten); $d$. (haarolie en alle welriekende oliën, reukwaters en andere reukwaren); e. (speelkaarten) met $30 \%$; 1 post t.w. (geweren, karabijnen en buksen, revolvers en pistolen) met $40 \%$ en 1 post (vuurwerken) met $50 \%$.

Zeer hoog zijn nog o.a. belast: aardappelen met $f 1.80$ per H.L.; buskruit met $f 3$.- per K.G.; bier met $f 0.20$ per L.; wijn (niet mousseerende) met $f 0.60$, mousseerende met $f 1.20$ per $\mathrm{L}$; gedistilleerd met $f 2.50$ per L. van $50 \%$; houtgeest (niet bestemd om door vermenging met binnenlandsch gedistilleerd, als brandspiritus te dienen) met $f$ 4.- per L.; sigaren met 2.1 cent per stuk benevens $60 \%$ van de waarde; sigaretten met 0.6 cent per stuk en $30 \%$ van de waarde; tabak (in rollen of bladen) met $f 2.50$ en gekorven met $f 3.50$ per K.G.; thee met 60 ct. per K.G.; benzine en gasoline met $8 \mathrm{ct}$. per $\mathrm{L}$.

Voor het overige zijn alle niet met name genoemde goederen belast met $16 \%$ van hunne waarde; bij invoer wordt de waarde der goederen gesteld op den loopenden prijs in Suriname ten tijde der aangifte, terwijl onder den loopenden prijs in Suriname wordt verstaan de som die gerekend wordt door de eerste hand in het buitenland op den dag der aangifte voor levering in dit gewest te kunnen worden bedongen, zonder inbegrip van de Surinaamsche belastingen.

De vrijgestelde artikelen (18 met name genoemde) omvatten meest ruwe grondstoffen, als onbewerkt ijzer, staal, koper, lood, tin, enz.; verder boeken, drukpersen, dynamiet en andere ontplofbare middelen (met uitzondering van buskruit), emballage, gemunt en papier geld, machinerieën en werktuigen, stal- en kunstmest, veevoeder, vliegmachines.

Het bedrag der invoerrechten is hetzelfde ongeacht het land van herkomst der goederen.

De betaling der invoerrechten geschiedt volgens aangifte van den importeur; wanneer bij de visitatie der goederen onderworpen 
aan een invoerrecht naar de waarde, de daarmede belaste ambtenaren oordeelen dat de aangegeven waarde te laag is, wordt deze geschat door den Controleur der Belastingen, van wiens uitspraak hooger beroep is toegelaten bij den Raad van Beroep (bestaande uit 5 niet-ambtelijke leden).

Het onderstaande staatje geeft een overzicht van de opbrengst (in duizendtallen uitgedrukt) aan invoerrechten van $1912 \mathrm{t} / \mathrm{m}$ 1938.

$\begin{array}{llllll}1912 & f 1.340 & 1921 & f 1.586 & 1930 & f 1.792 \\ 1913 & -1.287 & 1922 & -1.626 & 1931 & -1.580 \\ 1914 & -1.145 & 1923 & -1.577 & 1932 & -1.421 \\ 1915 & -976 & 1924 & -1.516 & 1933 & -1.326 \\ 1916 & -1.027 & 1925 & -1.812 & 1934 & -1.330 \\ 1917 & -1.002 & 1926 & -1.757 & 1935 & -1.329 \\ 1918 & -877 & 1927 & -1.781 & 1936 & -1.365 \\ 1919 & -1.037 & 1928 & -1.843 & 1937 & -1.433 \\ 1920 & -1.681 & 1929 & -1.790 & 1938 & -1.459\end{array}$

Bij Verordening van 19 Mei 1925 (G.B. No. 65) werd bepaald dat, ter dekking van het geleden verlies op de ten behoeve van de bevolking gedurende de oorlogsjaren aangevoerde levensmiddelen, van 1 Januari 1926 af tot en met uiterlijk 31 December 1935 op het middel ,invoerrechten" geheven zullen worden 2 opcenten voor alle goederensoorten.

Bij Verordening van 30 November 1931 (G.B. No. 86) werd bepaald dat tot tijdelijke versterking der middelen gedurende de jaren 1932-1934 zullen worden geheven 10 opcenten van alle goederensoorten en wel nevens die genoemd in bovengenoemde Verordening; deze termijn verlengd tot 31 December 1935 en het aantal opcenten verhoogd tot 23 (Verordening van 3 Augustus 1932 G.B. No. 79).

Krachtens Verordening van 16 Mei 1935 (G.B. No. 93) worden van 16 Augustus 1935 af tot 31 December 1938 (deze termijn is nader verlengd tot 31 December 1941) 25 opcenten geheven van alle goederensoorten; tegelijkertijd zijn van 16 Augustus 1935 af vervallen de hiervoren genoemde Verordeningen van $19 \mathrm{Mei}$ 1925 en 30 November 1931 (zooals deze luidt ingevolge de Verordeningen voor 3 Augustus 1932 G.B. No. 79 en 15 October 1932 G.B. No. 98.

\section{Accijns op het binnenlandsch gedistilleerd.}

Tot tijdelijke versterking van de middelen werden gedurende 
de jaren 1916 t/m 191930 opcenten geheven op den accijns op het binnenlandsch gedistilleerd. (Verordeningen van 13 Augustus 1916 G.B. No 60, 16 Mei 1917 G.B. No. 84 en 17 Mei 1918 G.B. No. 94).

Van 1 Januari 1920 af werden de opcenten verhoogd tot 50 (Verordening van 30 December 1919 G.B. No. 85), terwijl tot nadere versterking der middelen van 25 Augustus 1920 af 50 opcenten werden geheven nevens de 50 opcenten hiervoren bedoeld (Verordening van 24 Augustus 1920 G.B. No. 56).

De termijn voor de heffing van 100 opcenten, welke met 31 December 1920 zou afloopen, werd in afwachting van de herziening van dit middel bij Verordening van 30 December 1920 (G.B. No. 119) verlengd en mitsdien de heffing van deze opcenten bestendigd.

De accijns werd bij Verordening van 10 Mei 1922 (G.B. No. 55) met ingang van dezen datum verhoogd van $f$ 100.- tot $f 200$.per H.L. van $50 \%$.

Er zijn in Suriname thans slechts 2 suikerfabrieken, welke behalve suiker ook rum produceeren.

De opbrengst voor den accijns gedurende de jaren $1912 \mathrm{t} / \mathrm{m}$ 1938 volgt hieronder. (de bedragen zijn in duizendtallen afgerond)

$\begin{array}{llllll}1912 & f 158.000 & 1921 & f 455.000 & 1930 & f 156.000 \\ 1913 & -163.000 & 1922 & -377.000 & 1931 & -123.000 \\ 1914 & -144.000 & 1923 & -161.000 & 1932 & -62.000 \\ 1915 & -114.000 & 1924 & -202.000 & 1933 & -78.000 \\ 1916 & -148.000 & 1925 & -200.000 & 1934 & -62.000 \\ 1917 & -205.000 & 1926 & -191.000 & 1935 & -50.000 \\ 1918 & -298.000 & 1927 & -197.000 & 1936 & -53.000 \\ 1919 & -351.000 & 1928 & -202.000 & 1937 & -57.000 \\ 1920 & -375.000 & 1929 & -140.000 & 1938 & -60.000\end{array}$

\section{Lucifersbelasting.}

Met ingang van 1 Januari 1918 verviel de Verordening van 22 Mei 1907 (G.B. No. 53), houdende bepalingen omtrent de belasting op lucifers, waarvoor in de plaats trad de ,Lucifersbelasting" (Verordening van 19 September 1917 G.B. No. 81).

Bij deze Verordening werd eene betere regeling getroffen voor de inning der belasting, waardoor een hoogere opbrengst van dit middel verwacht werd. Voor de heffing der belasting wordt thans gebruik gemaakt van zegels, welke voor een bepaald bedrag (namelijk dat der belasting) door het Bestuur voor de 
ondernemers worden beschikbaar gesteld en door hunne zorg op de doosjes geplakt.

De ondernemer is verplicht te zorgen dat ieder doosje onmiddellijk na de vulling wordt afgesloten door middel van zulk een zegel; ter voorkoming van fraude is het tevens verboden op het tijdstip van het einde der dagelijksche werkzaamheden in de onderneming gevulde doosjes voorhanden te hebben, die niet van het sluitzegel op de voorgeschreven wijze zijn voorzien.

De belasting bleef bij de nieuwe Verordening ongewijzigd vastgesteld op $\frac{1}{2}$ cent per doosje inhoudende ten hoogste 72 lucifers, en bracht in de jaren 1912 t/m 1938 in duizendtallen afgerond, op als volgt:

$\begin{array}{llllll}1912 & f 19.000 & 1921 & f 20.000 & 1930 & f 20.000 \\ 1913 & -21.000 & 1922 & -19.000 & 1931 & -17.000 \\ 1914 & -17.000 & 1923 & -19.000 & 1932 & -12.000 \\ 1915 & -17.000 & 1924 & -15.000 & 1933 & -12.000 \\ 1916 & -19.000 & 1925 & -18.000 & 1934 & -8.000 \\ 1917 & -19.000 & 1926 & -19.000 & 1935 & -5.000 \\ 1918 & -12.000 & 1927 & -18.000 & 1936 & -6.000 \\ 1919 & -20.000 & 1928 & -21.000 & 1937 & -9.000 \\ 1920 & -17.000 & 1929 & -17.000 & 1938 & -7.000\end{array}$

Groep B. Patenten

\section{Recht op den verkoop van gedistilleerd.}

Tot tijdelijke versterking van de middelen werd bepaald dat gedurende de jaren 1917, 1918 en 1919 op het recht voor de verlofbewijzen tot verkoop van gedistilleerd 20 opcenten zullen worden geheven. (Verordeningen van 13 Augustus 1916 G.B. No. 60, 16 Mei 1917 G.B. No. 84 en 17 Mei 1918 G.B. No. 94).

Het aantal opcenten werd van 1 Januari 1920 af verhoogd tot 50 (Verordening van 30 December 1919 G.B. No. 85), terwijl van 25 Augustus $1920 \mathrm{t} / \mathrm{m} 31$ December 1930 nevens de genoemde 50 opcenten nog 50 opcenten werden geheven (Verordening van 24 Augustus 1920 G.B. No. 56).

Het bij de Verordening van 24 December 1906 G.B. No. 52 opgenomen tarief werd bij die van 29 December 1937 G.B. No. 152 vervangen door een nieuwe waarbij het bedrag van het recht werd vastgesteld:

a. voor de tappers.

$f$ 150.- per jaar voor een debiet van $f 500$.- - of minder, be- 
nevens $f$ 10.- voor elke geheele som van $f$ 100.- waarmede het debiet $f 500$. - te boven gaat;

$b$. voor de grossiers:

$f$ 100. - per jaar voor een debiet van $f 1000$. - of minder, benevens $f 25$.- voor elke geheele som van $f 500$. - waarmede het debiet $f$ 1000.- - te boven gaat.

De opbrengst dezer belasting is geweest (in duizendtallen afgerond )over:

$\begin{array}{llllll}1912 & f 38.000 & 1921 & f 89.000 & 1930 & f 60.000 \\ 1913 & -37.000 & 1922 & -87.000 & 1931 & -59.000 \\ 1914 & -35.000 & 1923 & -77.000 & 1932 & -52.000 \\ 1915 & -32.000 & 1924 & -69.000 & 1933 & -40.000 \\ 1916 & -30.000 & 1925 & -65.000 & 1934 & -28.000 \\ 1917 & -35.000 & 1926 & -68.000 & 1935 & -24.000 \\ 1918 & -35.000 & 1927 & -64.000 & 1936 & -18.000 \\ 1919 & -35.000 & 1928 & -61.000 & 1937 & -18.000 \\ 1920 & -43.000 & 1929 & -63.000 & 1938 & -18.000 \\ & & & & \end{array}$

\section{Inkomstenbelasting.}

Tot tijdelijke versterking der middelen in 1917 werd bij Verordening van 30 Augustus 1916 (GB. 1917 No. 4) het tarief van 1905, zooals het in 1909 werd gewijzigd, voor het belastingjaar 1917 verhoogd en tevens bepaald dat opcenten zouden worden geheven en wel 1. voor inkomens van $f 1900-f 22002 \frac{1}{2}$ opcent, voor inkomens van $f 2200 .--f 2500$. -5 opcenten en voor inkomens van $f 2500$. - of meer $7 \frac{1}{2}$ opcent; voorts dat op de aanslagen op te leggen aan: $a$ aan in Suriname gevestigde stichtingen, die een bedrijf uitoefenen, aan in dit gewest gevestigde naamlooze vernnootschappen, commanditaire vennootschappen op aandeelen, coöperatieve of andere vereenigingen en onderlinge verzekeringmaatschappijen; $b$. aan buiten Suriname wonende vennooten van in dit gewest gevestigde vennootschappen onder eene firma en in dit gewest gevestigde commanditaire vennootschappen niet op aandeelen, zoomede aan buiten Suriname gevestigde vennootschappen, vereenigingen en stichtingen die in dit gewest persoonlijk of door een vertegenwoordiger of gemachtigde een bedrijf of beroep uitoefenen. 60 opcenten zouden worden geheven.

Voor de jaren 1918 en 1919 werd deze heffing van opcenten 
bestendigd bij de Verordeningen van 16 Mei 1917 G.B. No. 85 en 17 Mei 1918 G.B. No. 77.

Voor 1920 werd het tarief bestendigd bij Verordening van 29 Januari 1920 G.B. No. 15, waarbij tevens werd bepaald dat opcenten zullen worden geheven en wel:

$a$. van belastbare inkomens van $f 1.900-f 2.2002 \frac{1}{2}$ opc.

$\begin{array}{lllllll}", & , & , & , & -2.200--2.500 & 5 & \end{array}$

$b$. van stichtingen enz. 80 opcenten (inplaats van 60).

Voor het jaar 1921 werd het in 1917 gewijzigde tarief eveneens bestendigd, met bepaling evenwel dat op de aanslagen op te leggen over 1921 zouden worden geheven:

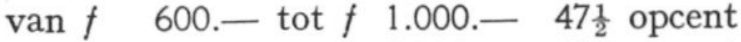

$$
\begin{aligned}
& \text {, - 1.000. - , - 2.000. - } 50 \text { opcenten }
\end{aligned}
$$

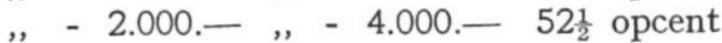

$$
\begin{aligned}
& \text {, - 4.000. - , - 6.000. - } 55 \text { opcenten }
\end{aligned}
$$

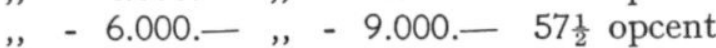

$$
\begin{aligned}
& \text { " - 9.000- , }-11.000 \text { - } 60 \text { opcenten } \\
& \text { " - 11.000- , - - 15.000. }-67 \frac{1}{2} \text { opcent }
\end{aligned}
$$

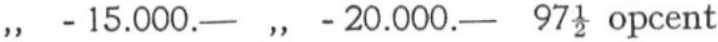

$$
\begin{aligned}
& \text { " } \quad-20.000 ., \quad-25.000 .-110 \text { opcenten }
\end{aligned}
$$

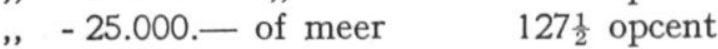

Op de aanslagen op te leggen aan vennootschappen enz. 110 opcenten.

Op 1 Januari 1922 trad in werking de ,Inkomstenbelasting 1922" (G.B. 1921 No. 112) en verviel tevens de Verordening van 29 Augustus 1905 (G.B. No. 64) op de inkomstenbelasting gelijk deze luidde na de daarin in 1909, 1915 en 1916 aangebrachte wijzigingen.

De belasting wordt thans geheven naar het bij art. 34 vastgestelde tarief. In dit tarief werd neergelegd het beginsel om den aanslag te stellen naar de middelsommen, vandaar de opklimming bij elke $f 50$. - in plaats van bij elke $f$ 100.- belastbaar inkomen. De minimum belastbare som werd bepaald op $f$ 500.-- en de minimum belasting op $f$ 7.-, met opklimming der verschuldigde belasting telkens met

$f$ 1.- bij een belastbaar inkomen van $f$ 500.- tot $f$ 1.000.-

$-1.25, ", \quad, \quad,-1.000$ - , , - 2.050.-

- 1.75 " " " " " $\quad$ " $\quad$ "

-2.- ", " " , " 
$f 2.50$ bij een belastbaar inkomen van $f$ 4.000.,$- ~ f f$ 4.500.-3.- ", " , , , - 4.500.— , - 5.000.-3.50, " " , , " $-4 .-", ", \quad, \quad, \quad, \quad$ " $-4.50, ", \quad, \quad, \quad, \quad, 6.500 ., ",-7.000$. -5.- ", ", $, \quad, \quad-7.000 .-,-8.000$. -6.- " " " $, ",-8.000 ., "-8.500$. - 7.- " " " $, \quad, \quad, \quad$ - 8.500.- " - 9.000.-8.- " " " ",$\quad$ - 9.000.— " - 10.000.-

Is het belastbare inkomen $f$ 10.000.- of meer, dan is verschuldigd eene vaste som van $f$ 735.-, benevens $f 12.50$ voor elk geheel bedrag van $f 100$.- waarmede het de som van $f 10.000$.te boven gaat.

De belasting der in Suriname gevestigde vennootschappen, vereenigingen en maatschappen bedraagt $f 7.50$ voor elk geheel bedrag van $f 100$. - van het zuiver inkomen en $f 12.50$ voor elk geheel bedrag van $f$ 100.- van de overwinst; voor de stichtingen is de belasting vastgesteld op $f 7.50$ voor elk geheel bedrag van $f$ 100.- van de zuivere opbrengst; voor de buiten Suriname gevestigde verzekeraars, die hun bedrijf in dit gewest uitoefenen op $f 7.50$ voor elk geheel bedrag van $f 100$.- van het belastbare inkomen.

Bij de Verordenung van 29 December 1932 (G.B. No. 120) is het minimum belastbaar inkomen vastgesteld op $f$ 800.(in plaats van $f 500 .-$ ); voor ongehuwden wordt het bedrag der belasting verhoogd met $10 \%$.

De opbrengst der belasting heeft, in duizendtallen afgerond bedragen in

$\begin{array}{llllll}1913 & f 114.000 & 1922 & f 233.000 & 1931 & f 484.000 \\ 1914 & -113.000 & 1923 & -281.000 & 1932 & -368.000 \\ 1915 & -113.000 & 1924 & -459.000 & 1933 & -268.000 \\ 1916 & -154.000 & 1925 & -586.000 & 1934 & -304.000 \\ 1917 & -230.000 & 1926 & -563.000 & 1935 & -284.000 \\ 1918 & -379.000 & 1927 & -468.000 & 1936 & -283.000 \\ 1919 & -461.000 & 1928 & -484.000 & 1937 & -414.000 \\ 1920 & -568.000 & 1929 & -461.000 & 1938 & -476.000 \\ 1921 & -565.000 & 1930 & -447.000 & & \end{array}$

\section{Buitengeroone inkomstenbelasting.}

Van de belastingschuldigen in de inkomstenbelasting, die ook gedurende den oorlogstoestand vermeerdering van belastbaar 
inkomen hebben genoten in de jaren 1915, 1916 en 1917 werd krachtens de Verordening van 30 Augustus 1916 (G.B. No. 13) een buitengewone inkomstenbelasting geheven, doch slechts over het bedrag waarmede die vermeerdering over eenig jaar de som van $f 5000$. - te boven ging; de belasting bedroeg $20 \%$ van het bedoelde bedrag en bracht in ronde sommen op in

$$
\begin{aligned}
& 1917 \text {. . . . . . . . } f \text { 18.000.- } \\
& 1918 \text {. . . . . . . }-70.500 \text { - } \\
& 1919 \text {. . . . . . . . }-176.000 \text { - } \\
& 1920 \text {. . . . . . . }-333.600 \text { - } \\
& 1921 . . . . . . \quad . \quad 286.700 \text { - }
\end{aligned}
$$

Tot tijdelijke versterking van de middelen in verband met de uitgaven voor aanleg, verbetering, onderhoud en reiniging van straten en wegen werd bij Verordening van 5 December 1928 (G.B. No. 104) bepaald dat op de aanslagen voor de inkomstenbelasting over de jaren 1929, 1930 en 19315 opcenten zouden worden geheven.

Deze heffing werd verlengd eerst tot en met 1934, daarna tot en met 1937 en laatstelijk tot en met 1940 (Verordeningen van 15 Mei 1931 G.B. No. 83, 14 Mei 1934, G.B. No. 86 en u Juni 1937 G.B. No. 47).

\section{Belasting op de huurwaarde.}

Deze belasting bracht, in duizendtallen afgerond, op in:

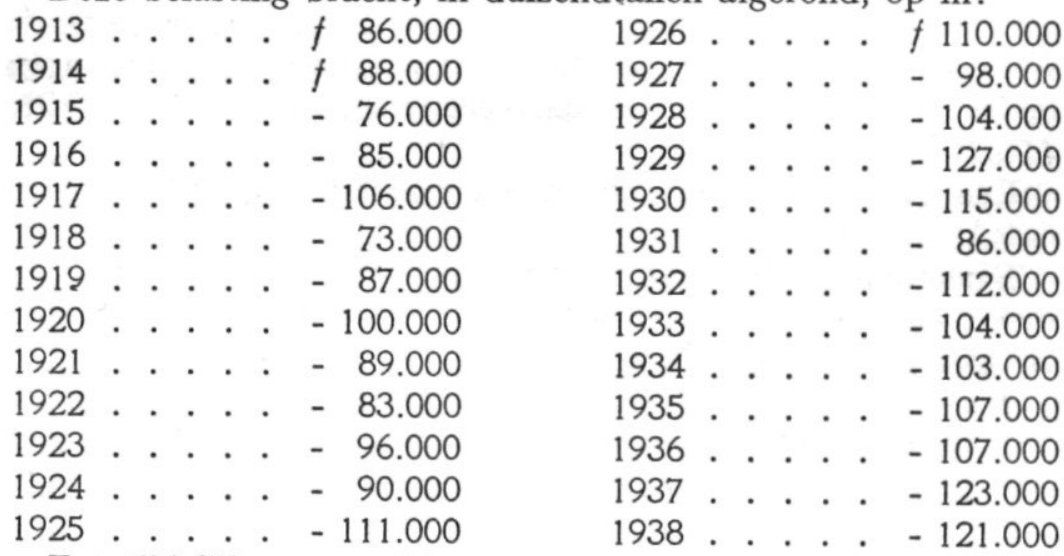

Tot tijdelijke versterking der middelen, in verband met de uitgaven voor aanleg, verbetering, onderhoud en reiniging van straten en wegen werd bij Verordening van 5 December 1928 (G.B. No. 104) bepaald dat gedurende de jaren 1929, 1930 en 
1931 op de aanslagen in de belasting op de huurwaarde van de gebouwen en de daarbij behoorende erven 25 opcenten zullen worden geheven.

De heffing van dit z.g. ,,wegengeld” werd verlengd t/m 1934 bij de Verordening van 15 Mei 1931 (G.B. No. 83), t/m 1937 bij de Verordening van 14 Mei 1934 (G.B. No. 86) en t/m 1940 bij de Verordening van 7 Juni 1937 No. 47.

Het ,wegengeld" bracht, in duizendtallen afgerond, op in:

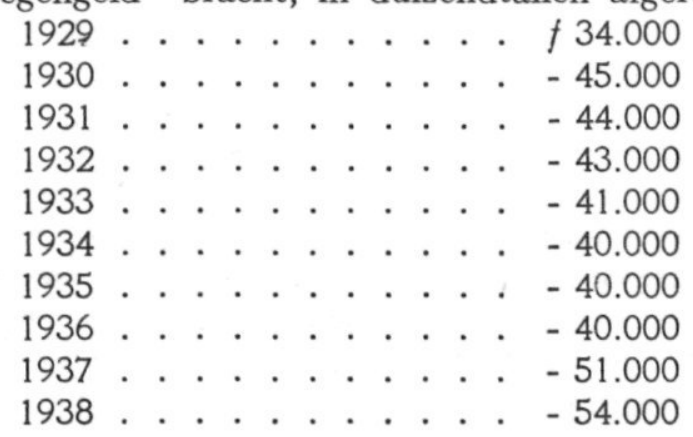

\section{Zegelrechten}

De Verordening van 5 Mei 1872 (G.B. No. 13) betreffende het recht van zegel werd bij die van 3 Augustus 1929 (G.B. No. 70) nader gewijzigd en aangevuld. Krachtens het bepaalde bij art. 3 van laatstgenoemde Verordening (welke kan aangehaald worden als de ,Zegelverordening" zijn sedert 1 November 1929 de formaatzegels van $f 1$. - $f 0.75, f 0.50, f 0.25$ en $f 0.15$ vervangen onderscheidenlijk door foormaatzegels van $f 1.50, f 1.12 \frac{1}{2}, f 0.75$, $f 0.37 \frac{1}{2}$ en $f 0.22 \frac{1}{2}$.

Een geldende tekst van de zegelverordening verscheen in G.B. 1930 No. 1.

Krachtens Besluit van 31 October 1929 (G.B. No. 83) zijn met ingang van 1 November 1929 nieuwe kalibers plakzegels en gestempeld papier uitgegeven.

Tot tijdelijke versterking der middelen gedurende 1935 en 1936 werd bij Verordening van 14 Mei 1934 (G.B. No. 87) bepaald dat op het zegelrecht zouden worden geheven 25 opcenten.

De heffing van deze opcenten werd voor 1937 en 1938 bestendigd bij Verordening van 12 Mei 1936 (G.B. No. 120) en gedurende 1939 en 1940 bij Verordening van 8 Juni 1938 No. 64) .

De opbrengst der zegelrechten heeft bedragen in duizendtallen afgerond in: 


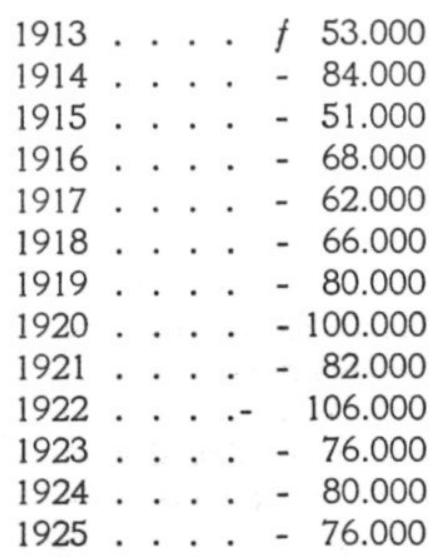

\section{Successie- en Overgangsrechten.}

De Publicatie van 1 Juni 1930 (G.B. No. 9) betrekkelijk het heffen der belasting op de erfopvolgingen in de Nederlandsche West-Indische bezittingen, welke in het jaar 1863 slechts geringe wijziging onderging, werd in afwachting eener algeheele herziening bij Verordening van 14 Mei 1934 (G.B. No. 71) gewijzigd; bij deze Verordening werd zoowel het recht van overgang als dat van successie met $50 \%$ verhoogd.

De opbrengst dezer belasting heeft, in duizendtallen afgerond, bedragen in:

$\begin{array}{llllll}1912 & f 5.000 & 1921 & f 1.000 & 1930 & f 2.000 \\ 1913 & -6.000 & 1922 & -6.000 & 1931 & -5.000 \\ 1914 & -8.000 & 1923 & -8.000 & 1932 & -7.000 \\ 1915 & -6.000 & 1924 & -10.000 & 1933 & -7.000 \\ 1916 & -5.000 & 1925 & -11.000 & 1934 & -9.000 \\ 1917 & -8.000 & 1926 & -21.000 & 1935 & -10.000 \\ 1918 & -6.000 & 1927 & -15.000 & 1936 & -8.000 \\ 1919 & -9.000 & 1928 & -4.000 & 1937 & -1.000 \\ 1920 & -7.000 & 1929 & -2.000 & 1938 & -6.000\end{array}$

10. Rij-en Voertuigenbelasting.

Bij Verordening van 5 December 1928 (G.B. No. 105) werd de belasting voor de jaren 1929 t/m 1931 bepaald:

$a$. voor elk tweewielig motorrij- of voertuig

I. niet gebezigd met voorspan-, zijspan- of aanhangwagen op f 25.- per jaar; 
II. gebezigd met voorspan-, zijspan- of aanhangwagen op $f$ 40.- per jaar;

$b$. voor elk motorrij- of voertuig op meer dan twee wielen:

I. indien het is ingericht voor het vervoer van nier meer dan 7 personen op $f$ 80.- per jaar;

II. en indien het is ingericht voor het vervoer van meer dan 7 personen of voor goederenvervoer op $f$ 100.- per jaar;

c. voor elk ander twee- of driewielig rij- of voertuig, niet vallende onder de omschrijving van de letters $a$ en $b$ op $f 5$.- per jaar;

$d$. voor elk ander rij- of voertuig op meer dan drie wielen, niet vallende onder de omschrijving van letter $b$ op $f 15$.- per jaar.

Deze verhooging der belasting werd voor de jaren $1932 \mathrm{t} / \mathrm{m}$ 1934 gehandhaafd bij Verordening van 15 Mei 1931 (G.B. No.84).

Tot tijdelijke versterking van de middelen werd bij de Verordening van 2 December 1932 (G.B. No. 110) bepaald dat over de jaren 1933 en 193410 opcenten op deze belasting zullen worden geheven.

Bij Verordening van 12 Juni 1934 (G.B. No. 76) werd bepaald dat met ingang op 1 Januari 1935 de belasting jaarlijks bedraagt, als volgt:

$a$. voor elk tweewielig motor rij- of voertuig, zoover voorspan-, zijspan- of aanhangwagen $f 20$.- en met een dergelijke wagen f30.- ;

$b$. voor elk motorrij- of voertuig op meer dan 2 wielen:

I. indien ingericht voor ten hoogste 7 personen $f 50$.- en indien ingericht voor meer dan 7, doch minder dan 12 personen f 70.- ;

II. indien ingericht als autobus, dan wel voor het vervoer van meer dan 12 personen $f$ 100.--;

III. indien ingericht voor het vervoer van goederen:

bij een laadvermogen tot 500 K.G. . . . . . . . . f60.", ", $\quad$ ", $\quad$ van $500-1000$ K.G. . . . . . . $\quad-75 .-$

IV. indien ingericht als tractor $f$ 90.-;

c. voor elk ander twee- of driewielig rij- of voertuig, niet vallende onder de omschrijving van de letters $a$ en $b f 5.50$.

$d$. voor elk ander rij- of voertuig op meer dan drie wielen, niet vallende onder de omschrijving van letter $b f 16.50$.

De opbrengst dezer belasting heeft in duizendtallen afgerond bedragen in 


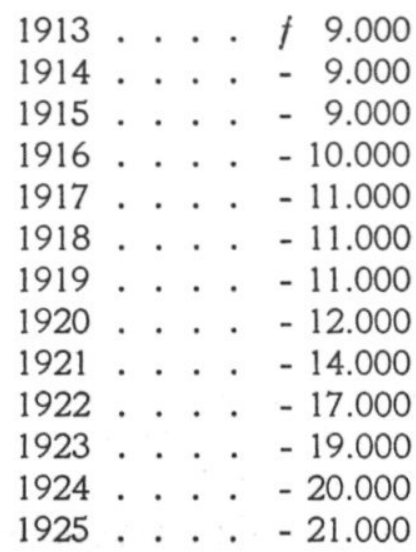

(Wordt vervolgd) 


\section{BOEKBESPREKING}

Studies on the fauna of Curaçao, Aruba, Bonaire and the Venezuelan islands door P. Wagenaar Hummelinck. Proefschrift aan de Utrechtsche Universiteit. 1940.

In dit werk wordt een ruime bijdrage geleverd tot de kennis van de dierenwereld van de eilanden, gelegen vóór de Venezuelaansche kust tusschen Trinidad en het schiereiland Goajira. Het betreft een 17-tal eilanden met een gezamenlijke oppervlakte van $2000 \mathrm{KM}^{2}$.

De Nederlandsche eilanden Curaçao, Aruba en Bonaire maken deel uit van deze eilanden. De belangrijkste andere eilanden zijn Margarita met 70.000 en Coche met 3.000 inwoners.

De schrijver heeft deze eilanden op een studiereis bezocht in de jaren 1936 en '37 met het doel in het bijzonder de land- en zoetwaterfauna te bestudeeren, behalve de vogels en de insecten. Ook werden ter vergelijking deelen van het naburige vasteland bezocht.

Reeds vroeger had de schrijver op de Nederlandsche eilanden van deze groep een studie gemaakt van de marine fauna, toen hij deel uitmaakte van de „Utrechtsche Antillen Excursie 1930”.

Uit den aard der zaak wordt bijzondere aandacht besteed aan het klimaat, regenval en waterverhoudingen, vegetatie en bodemgesteldheid, omdat die van belangrijke beteekenis zijn voor en grooten invloed zullen hebben op de land- en zoetwater fauna.

Ook wordt een kort overzicht gegeven van de ontwikkeling, meestal in negatieven zin, van flora en fauna na de ontdekking der eilanden.

Vele van de bovengenoemde gegevens worden door uitvoerige en overzichtelijke tabellen gestaafd en in opsommingen samengevat. Tevens wordt een uitvoerige bibliografie hieraan toegevoegd, terwijl een 16 tal kaarten de stations van waarneming en vele geographische en geologische gegevens van de bezochte eilanden in beeld brengen. 
Het 2de deel van het boek geeft een lijst en een overzichtelijke beschouwing van de zoogdieren, hagedissen en mollusken, die op de eilanden zijn aangetroffen. Wat de zoogdieren betreft is merkwaardig het voorkomen van een aap (een cebus-soort) op Margarita, wat wel samen zal hangen met de weelderige vegetatie van delen van dit eiland in tegenstelling met het xerophytische en zelfs woestijnachtige karakter van de flora der overige eilanden.

Bijzondere aandacht wordt besteed aan een hertsoort Odocoileus gymnotis, die in eenige varieteiten op enkele eilanden wordt aangetroffen, terwijl verwante soorten van verschillende delen van het vaste land van $Z$. Am. bekend zijn.

Verder blijken verschillende knaagdieren, een gordeldiersoort, een 10 tal vleermuizen en 2 soorten buideldieren voor te komen.

Ook achter deel 2 volgt een uitvoerige bibliographie.

Deel 3 geeft eigenlijk de slotbeschouwingen en conclusies van zöogeografischen en palaeogeographischen aard.

Zoo wordt gezegd, dat in de fauna van de Leeward groep 3 elementen kunnen worden onderscheiden nl. 1e een zuidelijk, nieuw element afkomstig dus van het vasteland van Zuid Ameri$\mathrm{ka}$, of veel verwantschap vertonende met de daar voorkomende soorten.

Speciaal de fauna van Margarita en tevens de eilanden ten Zuiden en Oosten hiervan bestaan hoofdzakelijk uit dit element.

Dit wijst op landverbindingen in het quartair van deze eilanden met het vaste land. $2 \mathrm{e}$ een zuidelijk ouder element, dat bestaat uit endemische soorten, die van waarschijnlijk Zuid-Amerikaanschen oorsprong zijn. Dit is vooral kenmerkend voor de eilanden, die westelijk van Margarita gelegen zijn. Hier ligt de veronderstelling voor de hand, dat er reeds een langdurige geographische afscheiding van het vaste land, waarschijnlijk reeds sinds het laat tertiair, bestaat.

Waarschijnlijk werden de Venezuelaansche eilanden bevolkt vanuit het westen en de Nederlandsche eilanden vanuit het westen, terwijl van Bonaire het eerste de verbindingen werden verbroken.

Ten slotte is er nog een 3de ouder, noordelijk element, dat uit endemische soorten bestaat, die vermoedelijk van de Antillen afkomstig zijn. Dit element vormt een belangrijk deel van de founa van Bonaire, Curaçao en Aruba en wijst op landverbindingen in het vroeg tertiair met een gebied, dat bewoond was door een specifieke Antillen fauna. Misschien zal later bij verder 
onderzoek kunnen blijken, dat ook enkele relicten van deze fauna in het Noordelijk deel van $Z$. Am. voorkomen.

De schrijver besluit met geologische beschouwingen over de aard en de plaats der genoemde voormalige landverbindingen.

Ook dit hoofdstuk wordt met een bibliographie besloten.

J. P. DE GaAy Fortman.

The Birds of Saba, by Stuart T. Danforth, in ,The Journal of Agriculture of the University of Puerto Rico", vol. 22, pp. 503-512 1939.

Als resultaat van zijn ornithologische onderzoekingen op Saba, van 23 Jan.-4 Febr. 1937, noemt de schrijver 25 vogelsoorten welke tot nu toe met zekerheid op, of nabij, dit eiland zijn waargenomen; hiervan zijn hem 23 soorten uit eigen aanschouwing bekend. Door wat langer voortgezette waarnemingen kan deze soortenlijst stellig nog aanzienlijk worden uitgebreid.

P. Wagenaar Hummelinck 


\section{EENIGE AANVULLINGEN OP DE ENCYCLOPAEDIE VAN NEDERLANDSCH WEST-INDIE}

DE BELASTINGEN IN SURINAME

II $(S l o t)$

DOOR

C. R. WEYTINGH

\section{Hondenbelasting.}

De Verordening van 3 Augustus 1894 (G.B. No. 32) waarbij een hondenbelasting voor Paramaribo werd ingevoerd is, behoudens enkele wijzigingen, nog steeds van kracht. Deze belasting werd bij Verordening van 2 Februari 1912 (G.B. No. 40) uitgebreid tot Nieuw-Nickerie en Albina.

De opbrengst (in duizendtallen afgerond) bedroeg in:

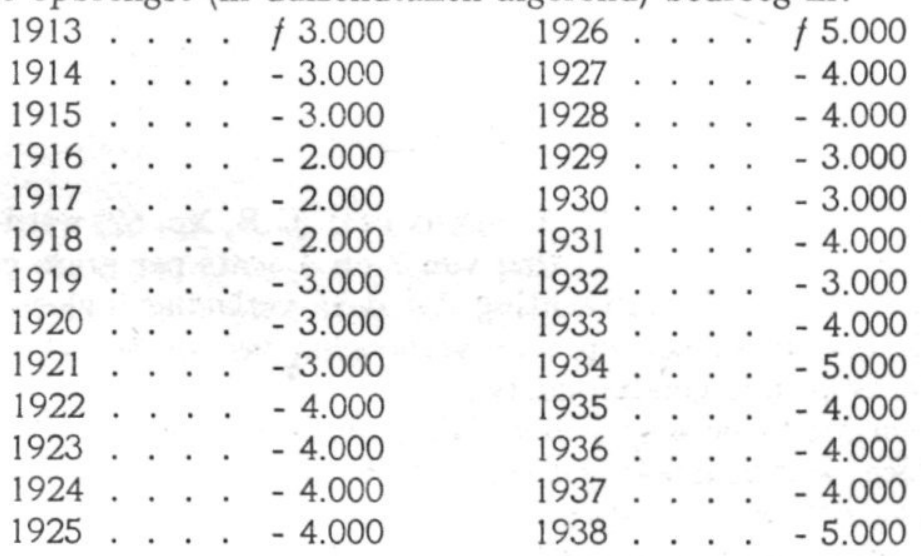

12. Port d'armes (Vuurwapenvergunningen)

De Verordening van 12 October 1898 (G.B. No. 49) werd bij die van 7 Februari 1930 (G.B. No. 73) ingetrokken.

Ingevolge het bepaalde bij art. 10 van laatstgenoemde Verordening moet men bevoegd zijn tot het voorhanden hebben van een vuurwapen.

$$
-353-
$$

West-Indische Gids XXII 
Met uitzondering van de daartoe bij art. 10 der laatstgenoemde Verordening aangewezen openbare ambtenaren en beambten, publiekrechterlijke lichamen, enz. zijn alleen bevoegd tot het voorhanden hebben van een vuurwapen zij, die voorzien zijn van een algemeene of bijzondere schriftelijke machtiging van den tot verstrekking daarvan bevoegden ambtenaar volgens de daarin opgenomen bepalingen en voorwaarden.

Voor eene vuurwapen-vergunning is verschuldigd $f 3$.- voor een geweer of een revolver; $f$ 10.- voor elk ander vuurwapen; de vergunning is ten hoogste, doch tevens als regel geldig voor één jaar.

De opbrengst bedroeg, in duizendtallen afgerond, in:

$\begin{array}{llllll}1913 & f 2.000 & 1921 & f 2.000 & 1930 & f 3.000 \\ 1914 & -2.000 & 1922 & -2.000 & 1931 & -8.000 \\ 1915 & -2.000 & 1923 & -2.000 & 1932 & -8.000 \\ 1916 & -2.000 & 1924 & -2.000 & 1933 & -7.000 \\ 1917 & -2.000 & 1925 & -3.000 & 1934 & -7.000 \\ 1918 & -2.000 & 1926 & -3.000 & 1935 & -7.000 \\ 1919 & -2.000 & 1927 & -2.000 & 1936 & -7.000 \\ 1920 & -3.000 & 1928 & -2.000 & 1937 & -8.000 \\ & & 1929 & -2.000 & 1938 & -8.000\end{array}$

Groep D. Domaniale heffingen.

13. Goudbelasting.

Bij Verordening van 28 Augustus 1931 (G.B. No. 62) werd het bedrag van de grondbelasting van 7 op 4 cents per gram goud vastgesteld, in de verwachting dat deze verlaging invloed ten goede zou uitoefenen op eene verhooging van de sedert jaren achteruitgaande goudproductie.

Toen de productie van dit metaal welke in 1931 slechts 143 K.G bedroeg, wederom was gestegen tot 385 K.G. in 1933, terwijl de stijging zich in 1934 voortzette, besloot het Bestuur de belasting weer op het oude peil - d.i. 7 cts per K.G. - te brengen (G.B. 1934 No. 70).

De belasting bracht (in duizendtallen afgerond) op in:

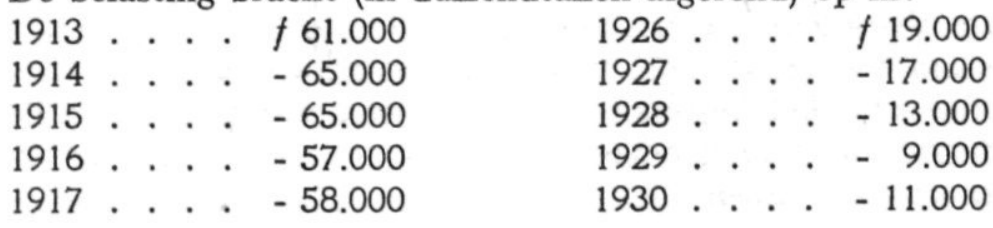




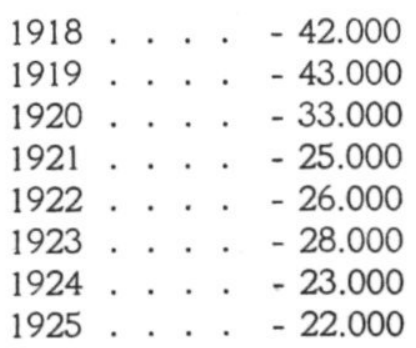

\begin{tabular}{|c|c|c|c|}
\hline 931 &.$\quad$. & & \\
\hline 1932 &.$\quad$. & & \\
\hline 933 &.. & & \\
\hline & . . & & \\
\hline & . . & & \\
\hline & . . & & \\
\hline & & & \\
\hline & & & \\
\hline
\end{tabular}

\section{Bauxietbelasting.}

Van bauxiet in welken vorm ook, hetzij gezuiverd, hetzij met andere bestanddeelen vermengd, in Suriname gewonnen, is krachtens de Bauxietbelasting 1919 (Verordening van 27 Maart 1918 G.B. 1919 No. 77) sedert 1 Januari 1920 een belasting verschuldigd ten bedrage van 25 centen per ton van duizend kilogrammen of gedeelten van een ton. Deze belasting wordt berekend overeenkomstig den uitslag van de weging van het bauxiet in den toestand waarin het verscheept wordt.

Voorschriften omtrent de formaliteiten die bij vervoer en opslag van bauxiet binnen Suriname en uitvoer daarvan uit dit gewest in acht moeten worden genomen en omtrent de maatregelen ter verzekering van de inning van deze belasting zijn gegeven bij Besluit van 30 December 1919 (G.B. No. 84).

Het bedrag der belasting werd met ingang van 20 Januari 1925 (Verordening van 19 Januari 1925 G.B. No. 6) van 25 cts teruggebracht tot $12 \frac{1}{2}$ cts per ton van 1000 K.G.

Bij Verordening van 19 Juni 1931 (G.B. No. 85) welke op een nader door den Gouverneur te bepalen tijdstip in werking zal treden, werd de belasting verhoogd tot 50 cts per ton van 1000 K.G.

De belasting heeft, in duizendtallen afgerond, bedragen in:

\begin{tabular}{|c|c|c|}
\hline 1922 &. & $f 3.000$ \\
\hline 1923 & . . & 3.000 \\
\hline 1924 & . & -14.000 \\
\hline 1925 & • & -11.000 \\
\hline 1926 & & - 5.000 \\
\hline 1927 & & - 22.000 \\
\hline 1928 & . & -25.00 \\
\hline 192 & & -26.000 \\
\hline & & -33.000 \\
\hline
\end{tabular}

1931 . . . . $f 22.000$

1932 .. . -15.000

1933 . . . -16.000

1934 . . . -13.000

1935 . . . -16.000

1936 . . . -32.000

1937 . . . -47.000

1938 . . . -48.000 


\section{Concessie- en vergunningsrecht voor bauxiet}

Bij de Bauxietverordening 1919 (Ver. van 27 Maart 1918 G.B. No. 76) werden bepalingen in het leven geroepen omtrent het doen van onderzoek naar de aanwezigheid en omtrent het ontginnen van bauxiet 1) in of op den bodem van Suriname.

De vergunning tot het doen van onderzoek wordt niet verleend voor een grootere oppervlakte dan 5000 H.A. Het te betalen recht bedraagt 1 cent per H.A. per jaar; de duur der vergunning is 1 jaar.

Geen concessie van domeingrond tot ontginning wordt uitgegeven voor minder dan één jaar en voor langer dan 50 jaren, noch voor een oppervlakte van meer dan 125.000 H.A. en van minder dan 1000 H.A.

De retributie bedraagt per H.A. 10 cts voor het eerste jaar, 20 cts voor het tweede, 50 cts. voor het derde, 75 cets voor het vierde en $f$ 1.- voor elk volgend jaar.

$\mathrm{Na}$ het $5 \mathrm{e}$ jaar moet de minimumopbrengst bedragen 10 ton van 1000 K.G. per H.A.

De opbrengst dezer rechten bedroeg, in duizendtallen afgerond in:

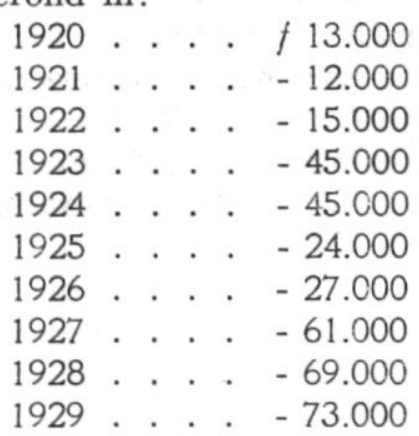

$$
\begin{aligned}
& \text { 1930. . . . f } 85.000 \\
& \text { 1931. . . }-66.000 \\
& \text { 1932. . . - } 53.000 \\
& \text { 1933. . . . }-42.000 \\
& \text { 1934. . . - } 48.000 \\
& \text { 1935. . . }-54.000 \\
& \text { 1936. . . . }-86.000 \\
& \text { 1937. . . . }-118.000 \\
& \text { 1938. . . }-118.000
\end{aligned}
$$

16. Retributie op hout en balata en concessie- en vergunningsrecht voor houtkap en voor balata.

\section{a. Houtkap.}

Bij Res. van 9 October 1922 No. 3592 (G.N. No. 77) werden bepalingen vastgesteld waaronder, in afwachting van de totstandkoming eener wettelijke regeling in zake den houtaankap

1) Een mineraal dat in hoofdzaak bestaat uit aluminiumhydroxied en in de eerste plaats dient als grondstof voor de bereiding van aluminium, voorts van aluin en van andere aluminiumverbindingen. 
concessies tot het bewerken van hout op domeingrond in Suriname worden verleend.

Voor terreinen gelegen ten Zuiden van de samenvloeiing van de Lawa en de Tapanahony werd het concessierecht vastgesteld op 1 cent per H.A. en per jaar en voor het overige deel van het gewest 2 cent per H.A. en per jaar, doch in geen geval minder dan $f$ 20.- per jaar.

Boven en behalve het concessierecht is verschuldigd een retributie op het verkregen product berekend overeenkomstig onderstaand tarief:

Bolletriehout . . . . . . . . . . . $f 2.50$ per $\mathrm{M}^{3}$

Letterhout . . . . . . . . -0.02 per K.G.

Vierk. bekapt of rond bouwhout . . . -0.50 per stam.

Gezaagd hout en kleine houtwaren . . -0.75 per M³.

Brandhout . . . . . . . . -0.06 per stapel Meter

Bast van gevelde boomen $f 0.10$ per 100 K.G.

Uit hout verkregen aetherische olie $f 0.15$ per K.G.

Voor houtskool werd later de retributie bepaald op $f 0.05$ per zak.

De retributie voor bolletriehout werd bij Res. van 14 November 1931 No. 3710 (G.B. No. 82) verlaagd tot $f 1.50$ per M³.

Voor verleende vergunningen tot het bewerken van hout werd ontvangen in:

\begin{tabular}{|c|c|c|}
\hline & . & $f$ 4.471.- \\
\hline 1913 & . & - 2.468.- \\
\hline 1914 & . & - 3.421.- \\
\hline 1915 & & - 1.412.- \\
\hline 1916 & . & - 8.411.- \\
\hline 1917 & . & - 7.198.- \\
\hline 1918 & . & 5.897.- \\
\hline 1919 & . & - 5.710.- \\
\hline 1920 & .. & $-28.132 .-$ \\
\hline 1921 & . & $-14.030 .-$ \\
\hline 1922 & . & - 6.478.- \\
\hline 1923 & . & - 12.990.- \\
\hline 1924 & . & - 12.289.- \\
\hline 2 & & - 14.243.- \\
\hline
\end{tabular}

$$
\begin{aligned}
& 1926 \text {. . . } f 18.235 \text { - } \\
& 1927 \text {. . . - 20.122.- } \\
& 1928 \text {. . . - 14.759.- } \\
& 1929 \text {. . . - 13.336- } \\
& 1930 \text {. . . - 14.199.- } \\
& 1931 \text {. . . - 10.944.- } \\
& 1932 \text {. . . - 8.313.- } \\
& 1933 \text {. . . - 7.252.- } \\
& 1934 \text {. . . - 7.377.- } \\
& 1935 \text {. . . - 7.690.- } \\
& 1936 \text {. . . - 4.029.- } \\
& 1937 \text {. . . - 5.917. } \\
& 1938 \text {. . . - 4.930.- }
\end{aligned}
$$

Aan retributie op het bewerkte hout werd geïnd in:
1912 . . . f 2.222.-
1913 . . . - 32.75-
1926 . . . $f 10.137$. -
1914 . . . - 4.852.-
1927 . . . - 13.289.-
1915 . . . - 1.256-
1928 . . . -15.892 -
1916 . . . - 1.765-
1929 . . . -13.475 . -
1930 . . . - 20.653.- 


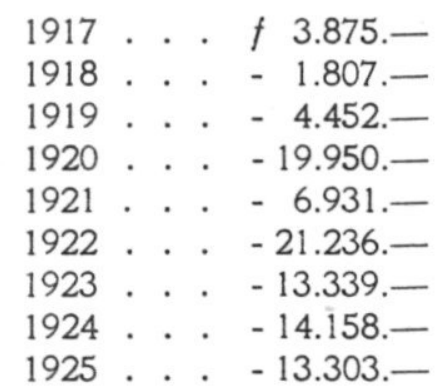

$1931 . . \quad f 16.508$ -

1932 . . . - 15.328.

1933 . . . -12.489 .

1934 . . . -12.510 -

1935 . . . -15.370 -

1936 . . . -18.966 -

1937 . . . -21.146 -

1938 .. -21.025 -

\section{b. Balata.}

Bij de Balataverordening 1914 (12 September 1914 G.B. No. 51 werden nieuwe bepalingen in het leven geroepen omtrent de exploitatie van balata in Suriname.

De uitgifte van concessies geschiedt volgens een perceelverdeeling in blokken.

Het concessierecht werd bepaald op $4 \frac{1}{2}$ ct. per jaar en per H.A.; behalve het concessierecht is de concessionaris verplicht een retributie te betalen ten bedrage van 15 cts. per K.G. verkregen balata.

Maatregelen ter verzekering van de inning der retributie werden vastgesteld bij Besluit van 12 Februari 1915 (G.B. No. 6).

Met het oog op de toenmaals lage balațaprijzen werd bij Verordening van $1^{-}$Mei 1928 (G.B. No. 25) besloten tot tijdelijke verlaging van de retributie; deze werd van $15 \mathrm{cts}$. teruggebracht tot $7 \frac{1}{2}$ cts per K.G. aangevoerde balata.

Bij Verordening van 8 Augustus 1928 (G.B. No. 62) werd het concessierecht, gerekend van 1 Januari 1928 bepaald op 3 cts. (in plaats van $4 \frac{1}{2}$ cts.) per jaar en per H.A. ; kort daarop en wel bij de Verordening van 28 December 1928 (G.B. No. 111) werd bepaald dat tot en met 31 December 1929 het concessierecht zal bedragen de helft van het verschuldigde, en de retributie 3 cts. per K.G., genoemde termijn werd eerst verlengd tot $31 \mathrm{De}-$ cember 1930 welke datum nader (bij Verordening van $11 \mathrm{Juli}$ 1920 G.B. No. 54) werd gewijzigd in 11 Juli 1930.

Bij Verordening van 24 October 1931 (G.B. No. 78) werden verminderd het concessierecht tot 1 cent per jaar en per H.A. en de retributie tot 3 cts. per K.G.

Op 1 Januari 1932 zouden alle concessiën welke tegen verlaagd concessierecht waren uitgegeven, vrij komen, waardoor in het Noordelijk deel des lands geen domeingrond voor de exploitatie van balata meer in handen van concessionarissen zou zijn. 
Het Bestuur maakte van deze gelegenheid gebruik om de blokken gelegen in genoemd Noordelijk deel des lands open te stellen voor hen, die als zelfstandig bleeder wilden trachten met de inzameling van balata een broodwinning te vinden.

Bij Besluit van 4 Februari 1932 (G.B. No. 10) werden daarop bepalingen in het leven geroepen omtrent de uitgifte van vergunningen tot exploitatie van balata ter behoeve van het kleinbedrijf; voor het verkrijgen van een vergunning (geldig voor één jaar) was een recht van $f 5$.- per blokperceel (van 5000 H.A.) verschuldigd.

Bij Verordening van 7 April 1933 (G.B. No. 37) werd het concessierecht verlaagd tot $\frac{1}{2}$ cent per jaar en per HA., en nader (bij Verordening van 19 Maart 1935 G.B. No. 45) gedurende het tijdvak van 1 Mei $1935 \mathrm{t} / \mathrm{m}$. 30 April 1938 tot $1 / 10$ cent per jaar per H.A. daar de balata in den laatsten tijd weer zeer moeilijk verkoopbaar, zelfs bijna onverkoopbaar werd en geen winsten opleverde.

Voor concessiën, welke vanaf 1 Mei 1938 t/m. 30 April 1939 zullen worden uitgegeven werd het concessierecht bepaald op 2/10 cts per H.A. (Verordening van 23 Maart 1938 G.B. No. 29).

Vergunnings- en concessierechten voor balata brachten op in:

\begin{tabular}{|c|c|c|}
\hline 912 & . & 9. - \\
\hline 1913 & & -222.600 \\
\hline 1 & & - 149.857.- \\
\hline & & -126.507 \\
\hline & & - 237.479. \\
\hline & & $-310.013 .-$ \\
\hline & & - 249.263.- \\
\hline & & - 280.636.- \\
\hline & & - 237.478.- \\
\hline & & - 181.796.— \\
\hline & & - 149.205.- \\
\hline & & - 175.587.- \\
\hline & & -174.221 \\
\hline & & - 188.762.- \\
\hline
\end{tabular}

1926 . . . $f$ 198.444.-

1927 . . . -146.421 -

1928 . . . - 58.245.-

1929 . . . - 41.866.-

1930 . . . -105.126 .

1931 . . - 22.273.

1932 . . - - - 120 -

1933 . . . - 4.917.-

1934 . . . - 6.231.-

1935 . . . 1.881 -

1936 . . . - 3.395.-

1937 . . . - 6.268.-

1938 . . - 7.185.-

Aan retributie van balata werd geïnd in:

\begin{tabular}{|c|c|c|c|c|c|}
\hline 12 & . & $f 108.122 .-$ & 1926 & . . . & $f$ 81.090.— \\
\hline 13 & & - 167.043.- & 1927 & & - 110.465.- \\
\hline 1914 & & - 97.912.- & 1928 & & - 36.835.- \\
\hline 1 & & - 82.782.- & 1929 & & - 12.831.- \\
\hline 1 & & -114.7 & 1930 & & - 64.376.- \\
\hline & & - 132.835.- & & & - 61.775.- \\
\hline
\end{tabular}




$$
\begin{aligned}
& 1918 \text {. . . f 99.629.- } 1932 \ldots . . f \text { 1.256.- } \\
& 1919 \text {.. . - 68.553. } 1933 . . .3 .193 . \\
& 1920 \text {.. - 66.760- } 1934 \text {. . - 7.602.- } \\
& 1921 \text {.. . - 72.905- } 1935 \text {.. . - 2.516- } \\
& 1922 \text {.. . - 81.726- } 1936 \text {. . - 3.480.- } \\
& 1923 \text {. . . - 94.335- } 1937 \text {. . - 5.724.- } \\
& 1924 . .5-82.871 . \quad 1938 . .2-7.992- \\
& 1925 \text {. . . - 105.476.- }
\end{aligned}
$$

Met 1 Maart 1915 werd voor een proefneming met het kleinbedrijf in de goudindustrie een terrein groot 7400 H.A. (gelegen ten Oosten van de Saramacca) beschikbaar gesteld tegen betaling van een concessierecht van minstens 10 ct. per H.A.

Aan concessierecht werd (in duizendtallen afgerond) ontvangen in:

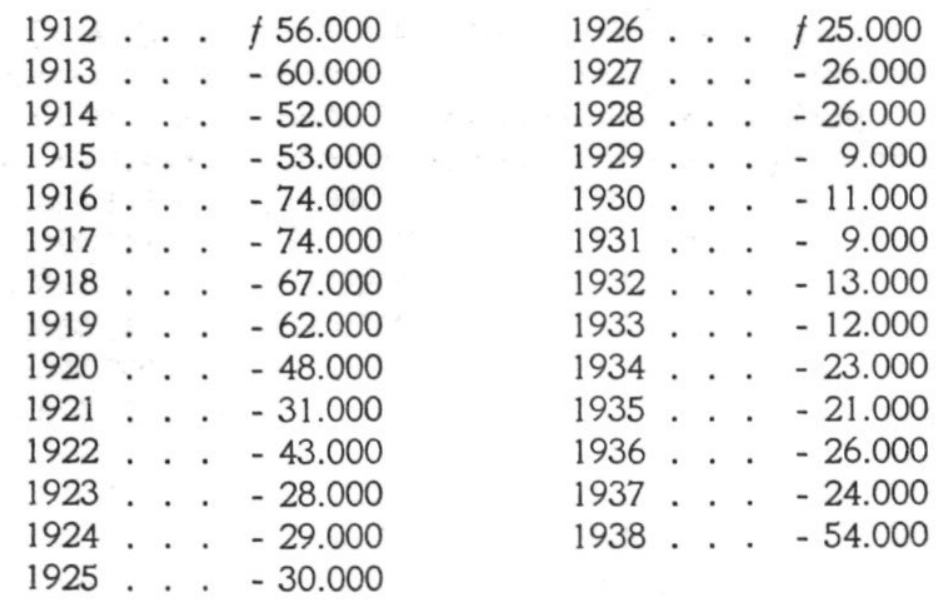

$$
\text { Groep E. Retributiën. }
$$

18. Weeg-, roei- en bergloonen en entrepôt-rechten.

De weeg- en roeiloonen, zoomede het opslagloon en het entrepôt-recht vastgesteld bij de Verordening van 5 December 1908 (G.B. 1909 No. 16) werden bij die van 31 December 1926 (G.B. No. 134) gewijzigd en nader bepaald, als volgt:

$A$. het weegloon:

1. voor varkens, geiten en schapen, per stuk . . . . 15 cts 
2. voor runderen en niet met name genoemde dieren per stuk . . . . . . . . . . . . . . . . . . $50 \mathrm{cts}$

3. voor goud, zilver en andere edele metalen, gouden en zilveren voorwerpen en edelgesteenten, per 10 gram of gedeelte daarvan . . . . . . . . . 3 cts

4. voor alle andere goederen per $100 \mathrm{~K}$.G. of gedeelte daarvan . . . . . . . . . . . . . . 3 cts $B$. het roeiloon:

per vat . . . . . . . . . . . . . $50 \mathrm{cts}$ C. het opslagloon per etmaal of gedeelte daarvan:

1. per vat voor elke $125 \mathrm{~L}$. inhoudsruimte . . . 2 tot $4 \mathrm{cts}$ al naar gelang de opslag geschiedt op niet overdekte steigers of terreinen, dan wel in een afgesloten of niet-afgesloten bergplaats.

Voor andere voorwerpen bedraagt het opslagloon alsvoren 5 tot 9 cts.

Voor levende dieren is het opslagloon vastgesteld op 15 cts. per stuk voor varkens, geiten en schapen en op 35 cts per stuk voor runderen en niet met name genoemde dieren.

Het entrepôtrecht bedraagt,per etmaal of gedeelte daarvan:

1. per vat inhoudende onverpakte natte waren

a. van $125 \mathrm{~L}$. inhoudsruimte of minder $1 \frac{1}{2} \mathrm{ct}$.

$b$. van meer dan $125 \mathrm{~L}$. inhoudsruimte, per $125 \mathrm{~L}$. of gedeelte daarvan $1 \mathrm{ct}$.

2. voor alle andere voorwerpen:

per $1 / 10 \mathrm{M}^{3}$ of gedeelte daarvan $2 / 5$ ct.

De opbrengst dezer rechten heeft (in duizendtallen afgerond) bedragen in:

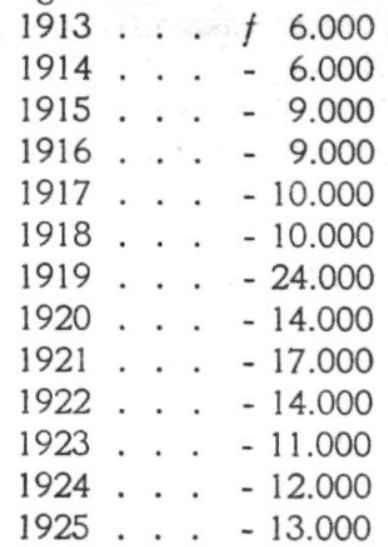

\begin{tabular}{|c|c|c|}
\hline 1926 & . . & $f 14.000$ \\
\hline 1927 & . . & -16.000 \\
\hline 1928 & & -14.000 \\
\hline 1929 & & -14.000 \\
\hline 93 & & -16.000 \\
\hline 1931 & & -16.000 \\
\hline 1932 & & -20.000 \\
\hline 1933 & & -16.000 \\
\hline 1934 & & -15.000 \\
\hline 1935 & & -15.000 \\
\hline . & & - 18.000 \\
\hline & & - 17.000 \\
\hline
\end{tabular}




\section{Marktvergunningen.}

Met betrekking tot het marktwezen werd bij Verordening van 22 Maart 1929 (G.B. No. 59) een regeling getroffen; bij Besluit van 11 November 1929 (G.B. No. 87) werden de marktplaatsen aangewezen.

Er zijn thans 5 overdekte markten en enkele andere open marktplaatsen.

De opbrengst bedroeg (in duizendtallen) in:

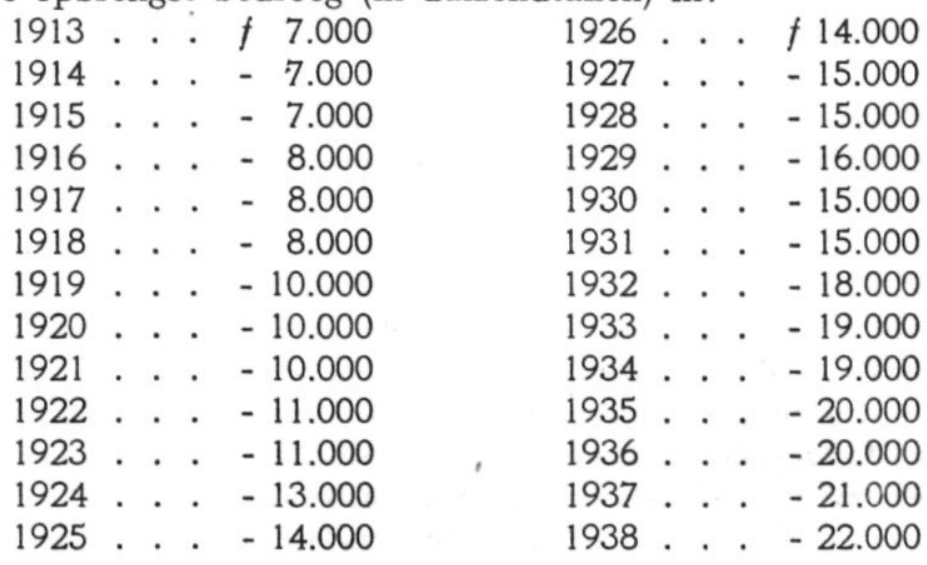

20. Begrafenisrechten.

In 1913 werd de algemeene begraafplaats ,Willem Jacobus Rust" gesloten, nadat het jaar te voren de nieuwe algemeene begraafplaats ,Veldrust” was aangelegd; voor het begraven van een lijk op deze begraafplaats werd het recht vastgesteld op $f$ 5.(Verordening van 25 Mei 1912 G.B. No. 46).

Bij Verordening van 23 Angustus 1926 (G.B. No. 117) werden de begrafenisrechten opnieuw geregeld; het begrafenisrecht werd toen vastgesteld

a. voor Paramaribo

op de begraafplaats Nieuwe Oranjetuin, daaronder begrepen het z.g. Nieuwe Kerkhof op $f$ 100.- ;

op een andere algemeene begraafplaats op $f$ 10.- ;

$b$. voor Nieuw-Nickerie op $f$ 10.- ;

c. voor de overige districten op $f 5$. -

Voor het vervoeren van een lijk uit Suriname wordt een recht van $f$ 100.- geheven.

Het begrafenisrecht heeft opgebracht in 


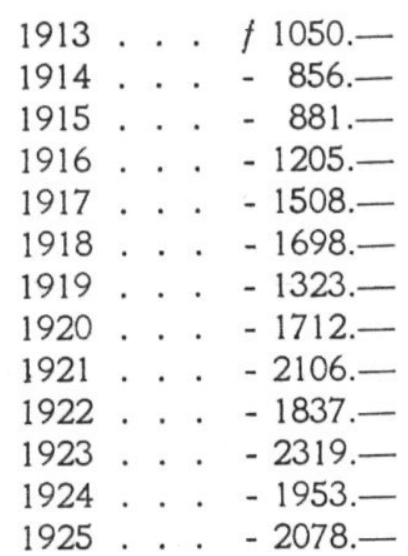

$$
\begin{aligned}
& 1926 \text {. . . f 1976.- } \\
& 1927 \text {. . . - 2183.- } \\
& 1928 \text {. . . - 1853.- } \\
& 1929 \text {.. . - 2341.- } \\
& 1930 \text {. . . - 1574.- } \\
& 1931 \text {. . - 1758.- } \\
& 1932 \text {. . . - } 1136 \text { - } \\
& 1933 \text {. . . - 1568.- } \\
& 1934 \text {. . . - 1366.- } \\
& 1935 \text {. . . - 904.- } \\
& 1936 \text {. . . - 1449.- } \\
& 1937 \text {. . - } 1175 \text { - } \\
& 1938 \text {. . . - 1213.- }
\end{aligned}
$$

\section{Opbrengst schoolgelden.}

Op de gouvernementsschool te Nieuw-Nickerie wordt van af 1 Januari 1913 schoolgeld geheven en wel voor elken leerling $f 1$.- per maand, voor twee of meer kinderen uit één gezin is voor elk het schoolgeld $f 0.25$ per maand minder (ook over vacantiemaanden is schoolgeld verschuldigd (Besluit van 22 November 1912 (G.B. No. 92).

Aan de van Sypesteynschool te Paramaribo werd van af 1 November 1915 een $8 \mathrm{e}$ klasse toegevoegd en het schoolgeld van deze klasse bepaald op $f$ 5.- per maand per leerling (Besluit van 29 September 1915 G.B. No. 63).

Vanaf 1 November 1929 wordt ingevolge Besluit van 16 October 1929 (G.B. No. 77) schoolgeld geheven:

A. op de Hendrikschool:

$1^{\circ}$. van ouders of verzorgers met een jaarlijksch inkomen van $f$ 1500.- of minder in de $1 \mathrm{e}$ en $2 \mathrm{e} \mathrm{kl}$. $f$ 5.- per maand

$$
\begin{aligned}
& \text { ", , 3e en } 4 \mathrm{e} k \mathrm{kl} \text { - 6.-, , , } \\
& \text { ", "5e en 6e kl. } f \text { 7.- ", , } \\
& \text { ", , 7e en } 8 \mathrm{e} \mathrm{kl} \text {. - 8.- , , }
\end{aligned}
$$

$2^{\circ}$. van ouders of verzorgers met een jaarlijksch inkomen van $f 1501-\mathrm{t} / \mathrm{m} . f 3000 .-$ in de $1 \mathrm{e} \mathrm{kl}$. $f$ 6.- per maand

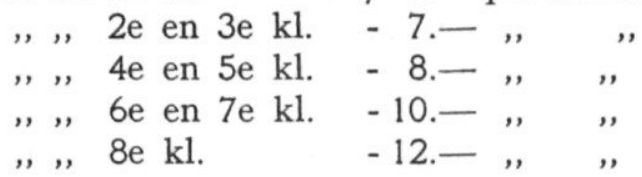

$3^{\circ}$. van ouders of verzorgers met een jaarlijksch inkomen van 


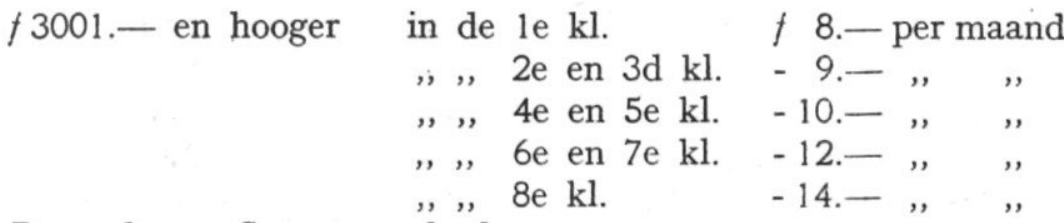

$B$. op de van Sypesteynschool

$1^{\circ}$. van ouders en verzorgers met een jaarlijksch inkomen van $f$ 1000.- en minder

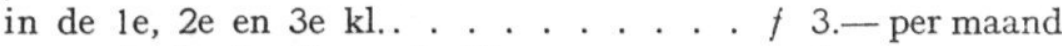

$4 \mathrm{e} 5 \mathrm{e}, 6 \mathrm{e}, 7 \mathrm{e}$ en $8 \mathrm{e} \mathrm{kl}$. . . . . . - 4.- ," ,

$2^{\circ}$. van ouders of verzorgers met een jaarlijksch inkomen van $f$ 1001.- $\mathrm{t} / \mathrm{m} . f 2000$. -

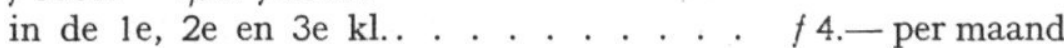

", $4 \mathrm{e}, 5 \mathrm{e}, 6 \mathrm{e}, 7 \mathrm{e}$ en $8 \mathrm{e} \mathrm{kl}$. . . . . . - 5.- ", ",

$3^{\circ}$. van ouders of verzorgers met een jaarlijksch inkomen van $f$ 2001.- en hooger

in de $1 \mathrm{e}, 2 \mathrm{e}$ en $3 \mathrm{e} \mathrm{kl} . . . . . . . .75$. . per maand

", 4e, 5e, 6e, 7e en $8 \mathrm{e} \mathrm{kl.} \mathrm{.} \mathrm{.} \mathrm{.} \mathrm{.} \mathrm{.} \mathrm{.} \mathrm{-6.-} \mathrm{,"} \mathrm{,"}$

Voor 2 of meer kinderen is zoowel op de Hendrikschool als op de van Sypesteynschool het schoolgeld voor elk hunner $f$.per maand minder voor de onder $A 1^{\circ}$ en $B 1^{\circ}$ genoemde; $f 1.50$ voor de onder $A 2^{\circ}$ en $B 2^{\circ}$ genoemde en $f 2$ - voor de onder $A 3^{\circ}$ en $B 3^{\circ}$ genoemde.

Bij Publicatie van 2 Juli 1929 (G.B. No. 39) werd afgekondigd de Wet van 26 Maart 1920 Stbl. No. 130 waarbij, tengevolge van een wijziging van het $2 \mathrm{e}$ lid van art. 159 van het RegeeringsReglement het bijzonder en openbaar onderwijs in Suriname werden gelijkgesteld.

Het kort daarop gevolgde Koninkl. Besluit van 4 December 1925 No. 23 in zake uitkeeringen uit 's Lands kas aan besturen van bijzondere scholen voor Lager Onderwijs in Suriname werd afgekondigd bij Publicatie van 7 December 1925 (G.B. No. 93).

De storting in 's Lands kas van het op de ondersteunde scholen voor uitgebreid en meer uitgebreid lager onderwijs geheven schoolgeld werd geregeld bij Besluit van 7 Februari 1930 (G.B. No. 15); volgens deze regeling moet het schoolgeld uiterlijk den 15 en van elke maand over de afgeloopen maand worden gestort.

Bij Verordening van 23 December 1930 (G.B. No. 96) werd bepaald dat het lager onderwijs kosteloos verkrijgbaar wordt gesteld voor kinderen wier ouders, voogden of verzorgers niet in de inkomstenbelasting zijn aangeslagen.

Bij Besluit van 15 Februari 1932 (G.B. No. 17) kwam een 
regeling tot stand, waarbij bepaald werd dat op de openbare scholen voor gewoon lager onderwijs van de ouders of verzorgers, die in de inkomsten belasting zijn aangeslagen en een kind op die scholen hebben, een schoolgeld van 10 cent per kalenderweek wordt geheven; voor twee of meer kinderen bedraagt het schoolgeld voor den tweeden hunner 5 cent; terwijl voor de overigen geen schoolgeld is verschuldigd.

In verband met de tijdsomstandigheden werd voor de jaren $1933 \mathrm{t} / \mathrm{m} .1939$ de heffing van schoolgeld op de openbare scholen geschorst. (Verordeningen van 7 December 1932 No. 114 e.a.).

De opbrengst van schoolgelden bedroeg (in duizendtallen afgerond) in:
1913 . . . $f 55.000$
1914 . . -57.000
$1915 \ldots-60.000$
1916 . . -64.000
1917 . . -65.000
1918 . . -73.000
1919 . . -72.000
1920 . . -70.000
1921 - . -73.000
1922 .. -76.000
1923 . . . -81.000
1924 . . . -82.000
$1925 . .-83.000$

1926. . . $f 129.000$

1927. . -125.000

1928. . - 77.000

1929. . . 71.000

1930. . . -150.000

1931. . -162.000

1932. . -163.000

1933. . -155.000

1934. . -152.000

1935. . . -148.000

1936. . . -148.000

1937. . -143.000

1938. . - 140.000

22. Examengelden.

Bij Verordening van 26 Mei 1917 G.B. No. 36 werden bepalingen vastgesteld tot het afleggen van het examen ter verkrijging van een akte landbouwkunde; het examengeld werd vastgesteld op $f$ 10.- .

De opbrengst bedroeg in:

\begin{tabular}{|c|c|c|c|c|}
\hline $912 .$. & . $\quad f$ 510.- & 1926 & & 925.- \\
\hline 1913. & $650 .-$ & 1927 & . & $-1.105 .-$ \\
\hline 914 & 530.- & 1928 & & $-1.335 .-$ \\
\hline & 645.- & 1929 & & $-2.705 .-$ \\
\hline & $825 .-$ & 1930 & & -2.835 \\
\hline & 995.- & 1931 & & -4.210. \\
\hline & $-1.040 .-$ & 1932 & & -3.020. \\
\hline & - 1.020.- & 1933 & & -7.252. \\
\hline & $-1.090 .-$ & 1934 & & -4.715 \\
\hline
\end{tabular}




$$
\begin{aligned}
& 1921 . . \quad j 1.210 .- \\
& 1935 . .+14.760 .- \\
& 1922 \text {. . . - -1.165.- } \\
& 1923 \text {. . . - 1.265.- } \\
& 1924 \text {. . . - } 1.310 . \\
& 1925 \text {. . . - 1.265.- } \\
& 1936 \text {. . . - 4.315.- } \\
& 1937 \text {. . . - 3.877.- } \\
& 1938 \text {. . . - 4.133.- }
\end{aligned}
$$

\section{Griffierechten, leges en justeerloonen.}

\begin{tabular}{|c|c|c|c|c|c|}
\hline 1912 & . & $f$ 4.581.- & 1926 & . & $f 10.604 .-$ \\
\hline 1913 & . & - 4.878.- & 1927 & . & -10.394 \\
\hline 1914 & . & - 4.108.- & 1928 & 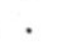 & - 12.019.- \\
\hline 1915 & . & - 3.203.- & 1929 & . & - 11.009.- \\
\hline 1916 & . & $-4.096 .-$ & 1930 & . & - 10.295.- \\
\hline 1917 & . & - 3.762.- & 1931 & . & - 8.207.- \\
\hline 1918 & . & - 2.738.- & 1932 & . & - 7.475.- \\
\hline 1919 & . & - 3.690.- & 1933 & . & - 7.130.- \\
\hline 1920 & . & $-3.951 .-$ & 1934 & . & - 7.484.- \\
\hline 1921 & . & - 3.959.- & 1935 & . & - 9.404.- \\
\hline 1922 & . & - 4.357.- & 1936 & . & - 8.917.- \\
\hline 1923 & . & $-4.200 .-$ & 1937 & . & - 8.633.- \\
\hline 1924 & . & $-6.614 .-$ & 1938 & . & - 7.811.- \\
\hline 1925 & & - 8.199.- & & & \\
\hline
\end{tabular}

De griffierechten, welke in 1872 werden vastgesteld en tot de minder belangrijke middelen van inkomsten worden gerekend brachten van $1913 \mathrm{t} / \mathrm{m}$. 1935 jaarlijks $\pm f 2.000$. - op.

De bepalingen omtrent de onder de benaming leges, ter Gouvernements-Secretarie te heffen rechten werden bij Verordening van 31 December 1923 (G.B. No. 19) herzien; tevens werd een nieuw tarief vastgesteld dat op 1 Januari 1924 in werking trad.

De opbrengst was in:

Op 1 Januari 1922 trad in werking de Verordening van 30 December 1916 (G.B. 1917 No. 79) ook genaamd de „Maten- en Gewichten Verordening 1916"

Bij Besluit van 12 Mei 1921 (G.B. No. 38) werd het justeerloon voor gewichten opnieuw vastgesteld dat van af 1 Januari 1922 wordt geheven.

Dit middel dat tot de weinig belangrijke wordt gerekend, bracht op in:
1912 . . . $f$ 424.-
1913 .. . - 439.-
1926 . . . $f 642 .-$
1914 .. . - 469.-
1927 .. . - 735.-
1915 . . . - 566.-
1928 . . . $-777 .-$
1929 . . . $-834 .-$ 


\begin{tabular}{|c|c|c|}
\hline 1916 & . & $f 611$. \\
\hline 1917 & . & -538 \\
\hline 1918 & . & - 789. \\
\hline 919 & & -605 \\
\hline 920 & & -676 \\
\hline 192 & & -560 \\
\hline 1922 & & - 709.— \\
\hline 192 & & $-605 .-$ \\
\hline 192 & & $-655 .-$ \\
\hline & & \\
\hline
\end{tabular}

\begin{tabular}{|c|c|c|}
\hline 30 . & . . & $f 717 .-$ \\
\hline 31 & . & -594 \\
\hline & & $-741 .-$ \\
\hline & & - 629.- \\
\hline & . & - 703.- \\
\hline & . & - 646.- \\
\hline & . & -627. \\
\hline & . & -382 \\
\hline & & -643 \\
\hline
\end{tabular}

Groep F. Heffingen van bijzonderen a rd

\section{Geneeskundige belasting.}

De geldelijke toestand waarin de groot-landbouwbedrijven ten gevolge van de crisis verkeerden, maakte het in het jaar 1931 noodzakelijk dat aan deze bedrijven een verlichting van lasten werd verleend; bij Verordening van $18 \mathrm{Juli}$ (G.B. No. 52) werd daarom de heffing van de geneeskundige belasting voor het jaar 1931 geschorst; om dezelfde reden werd ook de heffing voor 1932 geschorst bij Verordening van 12 Januari 1932 (G.B. No. 65).

In afwachting van een eventueele herziening van de grondslagen der belasting werd met het oog op de wenschelijkheid om den druk dezer heffing te verminderen, door gedeeltelijke verlaging van de toenmaals geheven wordende bedragen bepaald dat geheven zouden worden:

$f 1$. - (in plaats van $f 1.50$ ) per H.A. beplant met suikerriet en $f 0.50$ (inplaats van $f 1$.-) per H.A. beplant, met eenig ander landbouwproduct.

Voorts werd bepaald dat $1 / 4 \%$ (in plaats van $1 \%$ ) van de opbrengst van het product verkregen op gronden welke met andere producten dan suikerriet zijn beplant, zal worden geheven.

De opbrengst bedroeg, afgerond, in:

\begin{tabular}{|c|c|c|c|c|}
\hline 13. & $f 37.000 .-$ & 1926 & 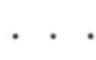 & $f 73.000 .-$ \\
\hline 14 & $-40.000 .-$ & 1927 & & - 63.000.- \\
\hline & $-53.000 .-$ & 1928 & & - 75.000.- \\
\hline & $-48.000 .-$ & 1929 & & - 72.000.- \\
\hline & - 69.000.- & 1930 & & - 58.000.- \\
\hline & $-36.000 .-$ & 1931 & & -16.000 \\
\hline & - 76.000.- & 1932 & & nihil \\
\hline & & 1933 & & nihil \\
\hline
\end{tabular}




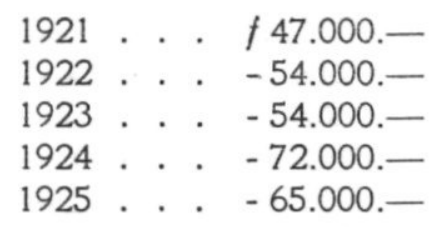

25. Belasting op enkele publieke vermakelijkheden.

Krachtens de Verordening van 14 Maart 1917 (G.B. No. 16) wordt belasting geheven van de opbrengst van voor het publiek toegankelijke bioscoopvoorstellingen of voorstellingen of uitvoeringen, gegeven door of met medewerking van personen, die van het geven van dergelijke voorstellingen of uitvoeringen een beroep of doel maken.

De belasting is verschuldigd door den ondernemer en bedraagt $10 \%$ van de verkoopwaarden der uitgegeven toegangsbewijzen.

Bij Verordening van 28 December 1920 (G.B. No. 116) is de belasting verhoogd tot $20 \%$ van de verkoopwaarde der uitgegeven toegangsbewijzen.

De opbrengst bedroeg afgerond in:

\begin{tabular}{|c|c|c|c|c|c|}
\hline 1917 & . & . $f$ 5.000.- & 1928 & . & $f$ 15.000.- \\
\hline 1918 & . & . $-4.000 .-$ & 1929 & . & $-14.000 .-$ \\
\hline 1919 & & - 5.000.- & 1930 & & $-15.000 .-$ \\
\hline 1920 & . & - 9.000.- & 1931 & & $-17.000 .-$ \\
\hline 1921 & & $-12.000 .-$ & 1932 & & $-15.000 .-$ \\
\hline 1922 & & $-13.000 .-$ & 1933 & . & -12.000. \\
\hline 1923 & & - 9.000.- & 1934 & & $-13.000 .-$ \\
\hline 1924 & & $9.000 .-$ & 1935 & & - 17.000.- \\
\hline 1925 & & $-15.000 .-$ & 1936 & & $-15.000 .-$ \\
\hline 1926 & & $-13.000 .-$ & 1937 & & $-16.000 .-$ \\
\hline 27 & & $-14.000 .-$ & 1938 & . & - 17.000.- \\
\hline
\end{tabular}

\section{Loterijbelasting.}

Volgens de bepalingen van de Publicatie van 26 Augustus 1828 (G.B. No. 9) werd van de in Suriname gehouden verlotingen een belasting geheven, bedragende bij verloting van onroerende goederen $3 \%$ van de waarde en van roerende goederen $10 \%$.

Tot versterking der middelen werd bij de Verordening van 27 December 1933 op de loterijbelasting (G.B. No. 103) - welke op 1 Januari 1934 in werking trad - de belasting op de loterijen opnieuw geregeld. 
De belasting bedraagt:

a. $15 \%$ van de volle waarde van de verloot wordende goederen of van het volle bedrag van het gezamenlijk aantal uitgegeven loten;

$b$. van het brutobedrag van elken getrokken geldprijs of van de volle waarde van elken getrokken goederenprijs $5 \%$, met dien verstande dat de prijzen, elk tot een bedrag van of met een waarde kleiner dan $f 5$.- buiten deze heffing vallen.

Voor verloting van goederen en voor geldloterijen waarvan de opbrengst strekt uitsluitend voor een liefdadig doel, bedraagt de belasting nochtans $10 \%$.

De belasting is verschuldigd door den houder van de verloting of loterij.

\section{Hoofdgeld voor onder contract verbonden immigranten.}

Met het oog op de bevordering van den landbouw werd de heffing over de jaren 1927 en 1928 geschorst (Verordening van 17 October 1927 G.B. No. 72).

Genoemde termijn werd, in afwachting van voorzieningen betreffende de afschaffing van het hoofdgeld, voor 1929 en volgende jaren verlengd. (Verordening van 5 December 1928 G.B. No. 106).

De opbrengst bedroeg afgerond in:

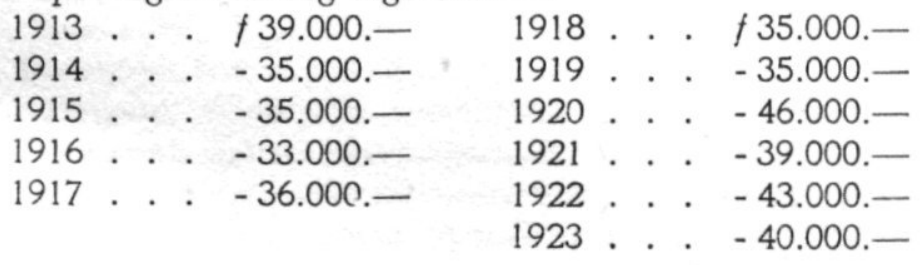

\section{Akkergelden.}

Daar het wenschelijk bleek het vorderen van het akkergeld voor gronden van geringe oppervlakte achterwege te laten, werd bij Verordening van 22 Februari 1916 (G.B. No. 67) bepaald dat voor gronden waarvan de oppervlakte minder dan één Hectare bedraagt, geen akkergeld wordt gevorderd.

De opbrengst was, in duizendtallen afgerond, in:

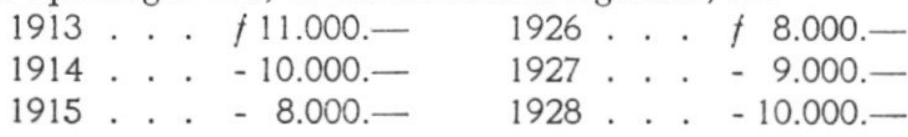




\begin{tabular}{|c|c|c|c|c|c|c|c|}
\hline 1916 & . & $f 11.000 .-$ & 1929 & . & . & $f$ & 9.000 - \\
\hline 1917 & & $-11.000 .-$ & 1930 & & . & - & 9.000.- \\
\hline 1918 & & - 8.000.- & 1931 & & . & - & 9.000.- \\
\hline 91 & & - 10.000.- & 1932 & & . & - & 8.000.- \\
\hline 920 & & - 10.000.- & 1933 & & . & - & 7.000.- \\
\hline 2 & & - 8.000.- & 1934 & . & . & - & 9.000.- \\
\hline & & - 9.000.- & 1935 & . & . & - & 8.000.- \\
\hline & & - 8.000.- & 1936 & . & . & - & 9.000. \\
\hline & & - 9.000.- & 1937 & . & . & - & 8.000.- \\
\hline & & - 10.000.- & 1938 & & . & - & $9.000 .-$ \\
\hline
\end{tabular}

Bronne n:

Verslagen van Bestuur en Staat van 1912 t/m. 1937. Begrootingen van $1912 \mathrm{t} / \mathrm{m} .1940$.

Gouvernements-Bladen. 